\title{
CASPIAN TERNS NESTING NEAR SPRUCE ISLAND, LAKE WINNIPEGOSIS, MANITOBA
}

\author{
by Roger M. Evans, David B. Krindle, and Mark E. Mattson, Department of \\ Zoology, University of Manitoba, Winnipeg, Canada.
}

A breeding colony of Caspian Terns (Hydroprogne caspia) was first reported in Manitoba "on a small shoal in a remote part of Lake Winnipeg" (Dunlop, 1915:500). O'Donoghue and Gowanlock (1919) subsequently reported a breeding colony of this species near Berens Island in Lake Winnipeg, and McLeod and Bondar (1953:6) found "many Caspian Tern nests" present on Vance's Reef, a gravel and boulder reef about 100 by 15 yards in size located in Dawson Bay in the northwest portion of Lake Winnipegosis. A breeding record of Caspian Terns at Gods Lake, Manitoba, has also been established, on the basis of eggs lodged at the Little Northern Museum, The Pas, Manitoba (personal corres., S. Waller and W. E. Godfrey). Both Bent (1921) and Godfrey (1966) have listed this species as breeding on Lake Winnipeg and Lake Winnipegosis. As part of a more general study of gulls and terns, we visited portions of Lake Winnipegosis in 1968 and 1969 in an attempt to obtain additional information about the breeding status and biology of Caspian Terns in this region.

In early June of 1968 and 1969, using a 16 -foot fibreglass boat, we investigated the northwest portion of Lake Winnipegosis, including the west shore and southeast portion of Dawson Bay, the reefs bordering Rowan Island, and Overflow Bay. These areas were found to contain colonies of Ring-billed Gulls (Larus delawarensis), Herring Gulls (L. argentatus), California Gulls (L. californicus), Common Terns (Sterna hirundo), Double-crested Cormorants (Phalacrocorax auritus) and, in the trees on Rowan Island, Great Blue Herons (Ardea herodias), but observations of Caspian Terns were limited to occasional glimpses of flying birds. On June 14, 1969, acting on a sugges- tion of commercial fishermen operating in Dawson Bay, we went some 20 miles east of our camp at Overflowing River, along the north shore of the lake, to a reef lying approximately one mile to the east of Spruce Island, where nests of several of the abovelisted species were found, as well as 310 nests of the Caspian Tern.

The reef used as a breeding site by the Caspian Terns appeared to be that referred to as the "reef east of Spruce Isl." by Vermeer (1969), and previously called "Goodman Island Reef" by McLeod and Bondar (1953), who described it as "a high, narrow reef about 600 yards long by a maximum width of 50 yards ... densely grown over with nettles and ragweed" (loc. cit., p. 6-7). The reef was less densely vegetated when we arrived in 1969 (Figure 1). In 1945, when Goodman Island Reef was visited by McLeod and Bondar, it contained a nesting area that they considered adequate for up to 1500 Double-crested Cormorant nests, but although guano deposits on the boulders indicated it had been used by that species in the past, no Cormorants were present at the time of their visit, nor were any noted in 1950 and 1951 when they surveyed the same reef from the air. These authors made no mention of other nesting birds on the reef, although they did record that on another reef, lying approximately three miles to the southeast, Doublecrested Cormorants were abundant, and nesting terns, gulls and pelicans (Pelecanus erythrorhynchos) were present and increasing in numbers between 1943 and 1951. Vermeer (1969) reported 645 cormorant nests on the reef east of Spruce Island at the time of his visit in 1969.

When we visited Goodman Island Reef, on June 14, 1969, breeding birds were abundant (Figure 2), and nest- 


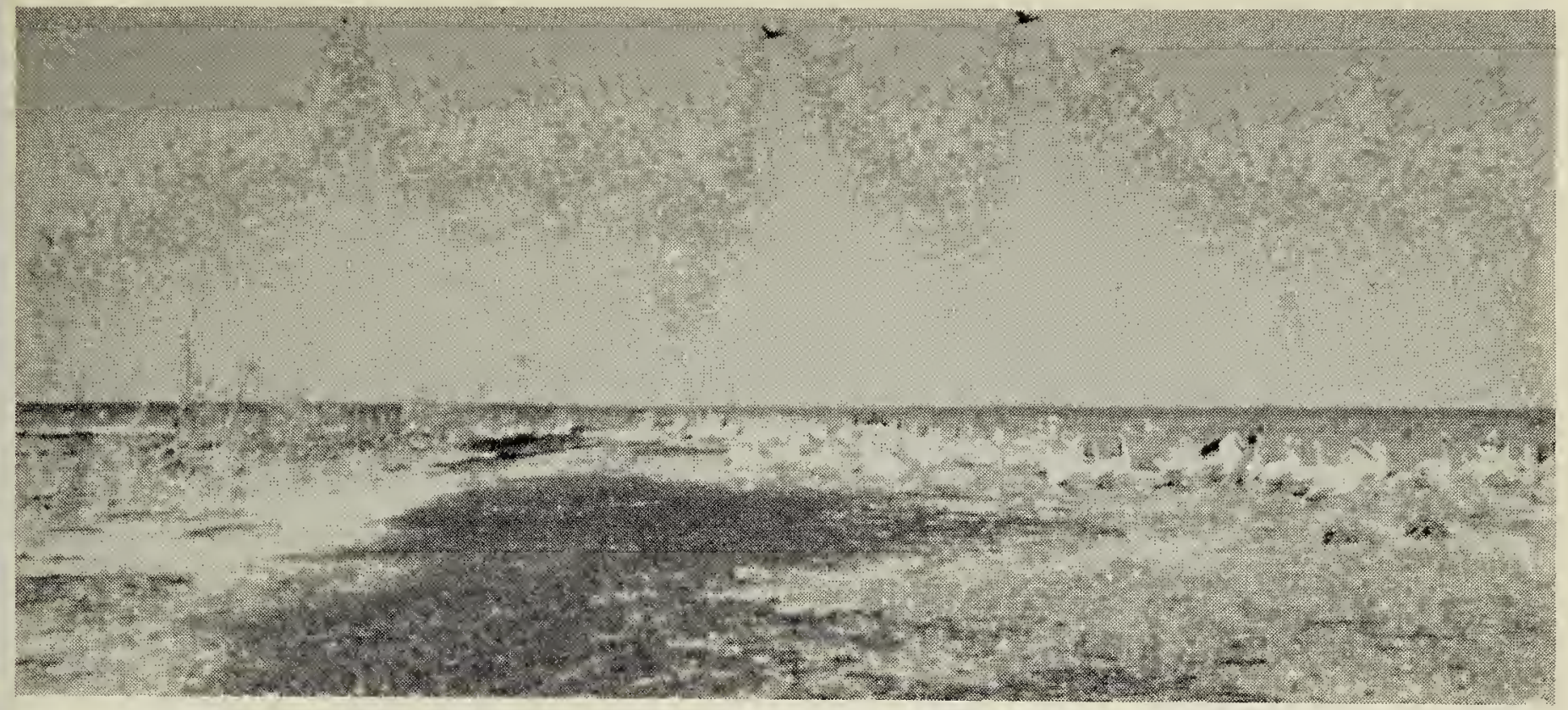

Fig. 1. Sparsely vegetated upper portions of reef containing Caspian Tern colony, near Spruce Island, Lake Winnipegosis.

ing areas covered up to an estimated 70 per cent of the available land surface. Caspian Terns, whose nests were only one to two meters apart, occupied three small areas of coarse sand and sparse vegetation on the north half of the reef. In addition to Caspian Terns, 307 White Pelican nests and 591 Double-crested Cormorant nests were counted, primarily along the sparsely vegetated higher portions of the reef. A small proportion of the Cormorant nests was located in a stand of dead trees that was present along the west shore of the south end of the island (Figure 1). Three Herring Gull nests were found near the middle of the reef, and Common Terns, which we estimated at approximately 200 pairs, occupied portions of bare sand and gravel at the periphery of the north and south ends of the reef. One hundred and twenty-four Ring-billed Gull nests, in numerous small clusters, were scattered along the length of the reef, primarily in stands of nettles. Although nest clusters of these various species tended to be partially separated from those of other species, mixed clusters were common, especially between pelicans and cormorants and, to a lesser extent, in regions of overlap, between Ring-billed Gulls, Caspian Terns, and Common Terns. In all cases where nests of different species were adjacent to each other, spacing between nests appeared to be typical for the species involved, thus suggesting the occurrence of spacing by interspecific territorial behaviour, a phenomenon previously reported, for example, in mixed colonies of Ring-billed, Herring, and California gulls at Dog Lake, Manitoba, by Moynihan (1956).

The three separate clusters of Caspian Tern nests contained 66,100 , and 144 nests respectively. As indicated in Table 1, the most common clutch size was two eggs (69 per cent of all nests), although single egg clutches were also common. Only seven nests, all in the largest cluster of nests, contained three eggs. According to the

Table 1. Nest contents of three Caspian Tern colonies located on Goodman Island Reef, near Spruce Island, Lake Winnipegosis, Manitoba, on June 14, 1969.

\begin{tabular}{|c|c|c|c|c|c|}
\hline Colony & 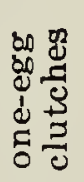 & 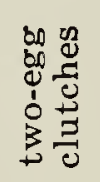 & 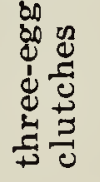 & 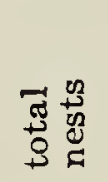 & 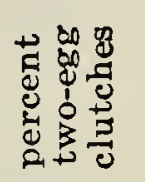 \\
\hline A & 17 & 49 & .. & 66 & $74 \%$ \\
\hline B & 34 & 66 & .. & 100 & $66 \%$ \\
\hline $\mathrm{C}$ & 38 & 99 & 7 & 144 & $69 \%$ \\
\hline Total & 89 & 214 & 7 & 310 & $69 \%$ \\
\hline
\end{tabular}




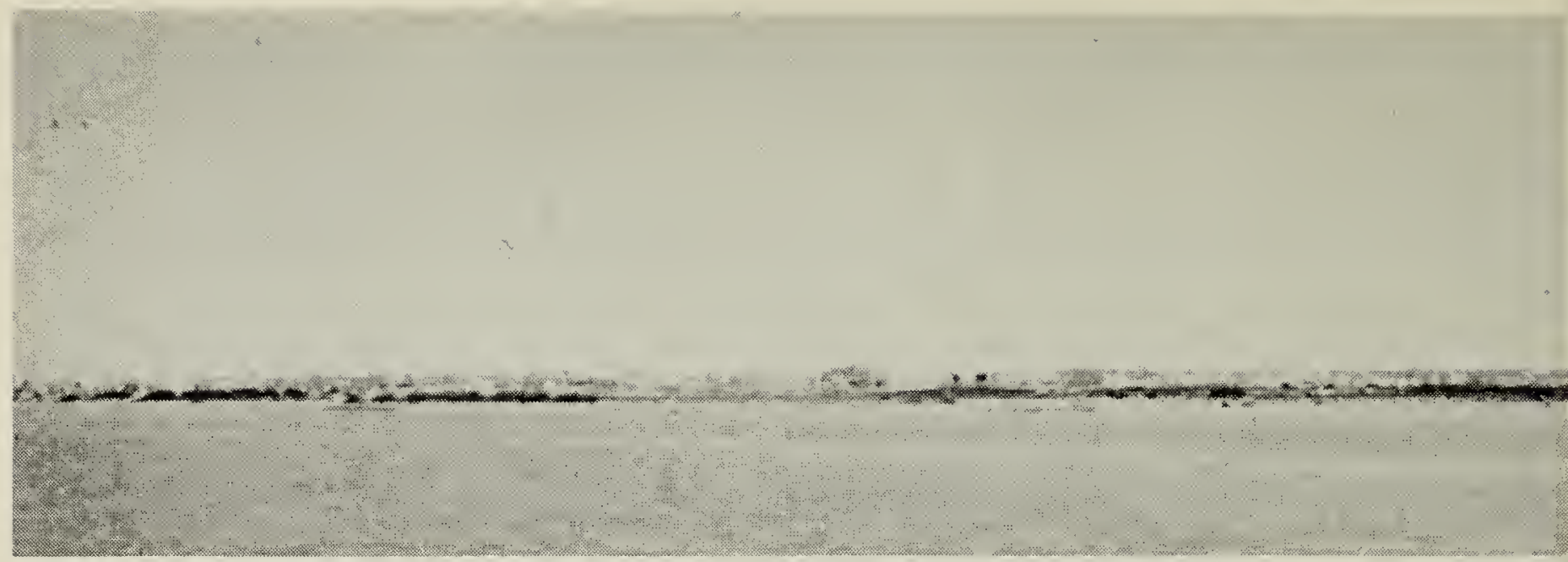

Fig. 2. Upflight of breeding birds as we approached Caspian Tern breeding colony near Spruce Island, Lake Winnipegosis.

information in Bent (1921: 206), twoegg clutches are the most common for this species in southern colonies, but clutches of three are more common in northern colonies, such as in Lake Michigan, where three-egg clutches may prevail. Our observations suggest that a clutch size of two is the most common as far north as the north end of Lake Winnipegosis, and that at that latitude, three-egg clutches are rare. O'Donoghue and Gowanlock (1919) also reported that the most common clutch size was two eggs in the colony they observed near Berens Island, Lake Winnipeg. The breeding season was well advanced when we visited Goodman Island Reef on June 14, hence it is unlikely that the majority of the one or two-egg clutches were incomplete at that time.

The eggs of the Caspian Terns on Goodman Island Reef were similar in size to those of Ring-billed Gulls, and in the absence of direct comparisons with the latter species might have posed difficulties of identification. As described above, however, differences in nesting habitat provided one difference between the two species, as did clutch size (Ring-billed Gull clutches on the reef contained predominantly the typical number of three eggs). In addition, as described in Bent (1921), the ground color of Caspian Tern eggs was slightly lighter in color, and the eggs contained considerably fewer and smaller spots compared to those of Ring-billed Gulls nesting adjacent to them. These differences appeared to correlate well with the differences in color and appearance of the nest substrate of the two species, the lighter eggs of the Caspian Terns blending well with the buff-colored sand at the nest site (Figure 3), while the darker and somewhat greenish tinted Ring-billed Gull eggs blended well with their nesting habitat of gravel covered with a growth of nettles.

On the day of our visit to Goodman Island Reef, one pipped Caspian Tern egg, presumably the first of the year, was present in the largest of the three nest clusters. In the hope of obtaining information on the development of behaviour in this species, we took the single pipped egg back to our camp at Overflowing River. Despite a three-hour boat trip in cool weather and choppy water, it hatched in our laboratory incubator at 11:35 p.m. of the same day. The onset of hatching for this colony in 1969 can therefore be taken as either June 14 or June 15. Two newly hatched Ringbilled Gulls, no more than two days of age, were also found on the reef at the time of our visit, indicating a marked similarity in the timing of the breeding cycle of these two species. In the Caspian Tern colony visited by O'Donoghue and Gowanlock (1919) none of the eggs examined was less than one week from hatching on July 13, thus indicating a hatching time of at least one month to six weeks later than for the Goodman Island Reef colony in 1969 . 
The young Caspian Tern appeared to be healthy, thriving at first on a diet of fish fillets and cat food. By the end of a week, however, it refused to eat, and even with the help of forcefeeding it failed to recover. Several observations of its food begging behaviour, obtained during the first few days after hatching, indicated a similarity to the observations of Arthur (in Bent, 1921: 207), who noted that when adult Caspian Terns arrived at the nest with fish for the young, the latter would "suddenly come to life, and, opening wide its little red beak, would chirp loudly ... and rush about waving its little wing stumps ...."

In contrast to our laboratory-reared Ring-billed Gull chicks, which were able to peck and obtain food placed in a container on the cage floor as early as their first day after hatching, the young Caspian Tern was never observed to obtain food that was placed at a level below its head, even when attempts were made to attract its attention by waving food held in forceps back and forth in front of it. These results suggest a high degree of inflexibility in the feeding behaviour of the young terns compared to the more polyphagous gulls. This inflexibility in feeding behaviour was further indicated by the typical posture taken when food begging, at which times it would invariably stretch its neck out and upwards, thereby direct-
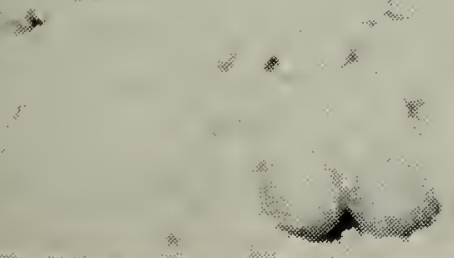

Fig. 3. One and two-egg clutches of light-colored Caspian Tern eggs in their shallow nests on bare sandy substrate. Colony near Spruce Island, Lake Winnipegosis, 1969. ing its open bill obliquely upwards, well above the level of its back. This posture, which under natural conditions presumably provides an efficient means of seizing fish brought to the nest by the parent (see Bent, 1921: 207 ), appeared to preclude the possibility of the young tern reaching down to obtain food from the bottom of the cage.

The calls emitted by the young Caspian Tern when begging for food sounded similar to the harsh calls typical of the adults when we entered their colony. We are unable at this time to suggest an hypothesis as to the biological significance of the similarity between the calls of the adult and young Caspian Tern, beyond the obvious conclusion that they indicate an early development of adult-type calls. It is to be hoped that further investigations of the development of communication in this and related species may provide a basis for more complete interpretation of the limited observations set forth here.

\section{Acknowledgements}

The observations described in this report were obtained while conducting studies supported by the National Research Council of Canada, The Chapman Fund of the American Museum of Natural History, the Canadian $\mathrm{Na}$ tional Sportsman's Shows, and the Northern Studies Committee, Univer. sity of Manitoba.

\section{LITERATURE CITED}

Bent, A. C. 1921. Life histories of North American gulls and terns. Smithsonian Inst. U.S. Nat. Mus. Bull. 113. Reprinted by Dover, 1963. $337 \mathrm{pp}$.

Dunlop, E. B. 1915. Notes on some Manitoba birds. Auk, 32:500-501.

Godfrey, W. E. 1966. The birds of Canada. National Mus. of Canada Bull. No. 203, Biological Series No. 73. 428 pp.

McLeod, J. A., and G. F. Bondar. 1953. A brief study of the Double-crested Cormorant on Lake Winnipegosis. Can. Field-Nat. $67: 1-11$.

Moynihan, M. 1956. California Gulls and Herring Gulls breeding in the same colony. Auk, $73: 453-454$.

O'Donoghue, C. H., and J. N. Gowanlock. 1919. Notes on the Caspian Tern (Sterna caspia) and the Parasitic Jaeger (Stercorarius parasiticus) in Manitoba. Can. FieldNat. $33: 1-6$.

Vermeer, K. 1969. The present status of Double-crested Cormorant colonies in Manitoba. Blue Jay, $27: 217-220$. 